\title{
FORECLOSURE OF CORPORATE MORTGAGES
}

\author{
MARGUERITE J. TRUSSLER*
}

\begin{abstract}
The economic downturn of the past few years has not occurred without effect on the area of corporate mortgage financing. The author traces the development of the legislation in Alberta with respect to corporate mortgage foreclosures. The mechanics of foreclosure under the legislation is also discussed in detail. Finally, the author explores the more recent decisions of the Alberta judiciary and comments on the apparent direction of the jurisprudence in this area.
\end{abstract}

\section{INTRODUCTION}

The downturn in the economy in 1981 which persisted throughout 1982 has caused a considerable increase in the foreclosure of mortgages and, in particular, mortgages given by corporations. Corporations involved in land speculation and commercial developments have been badly affected by the high interest rates and by the levelling off and, in fact, the dropping of land values. Activity in the market has been almost non-existent and whereas, in the past, corporations which owned property and had mortgages on them could always sell the property in a rising market for more than the security against the property, that option has ceased to exist.

As a result, a considerable amount of new case law has evolved, particularly from the numerous written decisions of Masters Funduk and Quinn which are essential reading for any lawyer involved in mortgage foreclosures. Interestingly enough, many of the new decisions and much of the case law being relied upon in today's practice result from the economically depressed times in the 1910's, '20's and '30's. The amount of law that evolved from 1939 until the 1970's is, for all practical purposes, almost negligible.

\section{LAW OF PROPERTY ACT}

\section{A. APPLICATION}

The Law of Property Act' came about when the Statutes of Alberta were revised in 1980 and it was thought fitting to place in one Act various provisions of numerous other Acts that related to property. The provisions of The Judicature Act, ${ }^{2}$ and The Land Titles Act, ${ }^{3}$ relating to mortgage foreclosure were made part of the Law of Property Act and are found in Part 5, "Enforcement of Mortgages and Agreements for Sale of Land." The relevant section with respect to corporate mortgages is section 43 which reads as follows:

43(1) Sections 41 and 42 do not apply to a proceeding for the enforcement of any provision

(a) of an agreement for sale of land to a corporation, or

(b) of a mortgage given by a corporation.

An initial question arises as to the applicability of this section. It is clear that where a mortgage is given by a corporation and that corporation is still the registered owner of the property, the section applies. There is also no difficulty where a mortgage is given by a corporation and then the

* B.A., LL.B. (U. of A.), LL.M. (U. of Melb.). Partner with the firm of Parlee, Irving, Henning, Mustard and Rodney in Edmonton.

1. R.S.A. 1980 , c. L-8.

2. R.S.A. 1970 , c. 193.

3. R.S.A. 1970 , c. 198. 
property is subsequently transferred to another corporation. Where the mortgage is given by an individual and subsequently transferred to a corporation, the court has held the section does not apply and that one has to look at the nature of the original mortgagor. ${ }^{4}$

A more difficult question arises where the original mortgagor was a corporation and the property was subsequently transferred to an individual. On a strict reading of s.43 together with s.62 of the Land Titles Act, ${ }^{5}$ there is no doubt that the individual no longer has the protection of ss.41 and 42 of the Law of Property Act. However, numerous lenders, particularly where there has been a corporate construction mortgage and the residences are subsequently transferred to individuals, have been reluctant to make use of s.43.

Another interesting situation arises where in one mortgage a company mortgages a parcel of land and an individual mortgages a different parcel of land, both to secure the same debt. Whether s.43 would apply was first raised in First Investors Corporation Ltd. v. 98898 Developments Ltd., a decision of Master Funduk of the 26th of February, 1982. ${ }^{6}$ On May 27th, 1982 , reasons for decision were given by Master Funduk in Robinson v. Carpenter. ${ }^{7}$ Master Funduk found that 5.42 of the Law of Property Act established a principle and s.43 was an exception to that principle. He decided that it was encumbent on the Plaintiff, in order to negate s.42, to establish that $\mathrm{s.43}$ applied. He further held that where, in that case, an agreement for sale of land is not to a corporation but to a natural person and a corporation, s.43 did not cover the situation, and there is no exception for the case where there are mixed co-purchasers or mixed co-mortgagors. Care must be exercised to prepare two separate mortgages where a mortgage is being taken both from an individual and from a corporation to secure the same debt. It is then possible to move more expeditiously to realize against the corporate mortgagor and not be tied to the statutory protection available to an individual.

\section{B. SECTIONS EXCLUDED}

The two sections excluded relate to an action on the covenant, the sale procedure that is to be followed, and the setting of the redemption period. Section 41 reads as follows:

41(1) In an action brought on a mortgage of land, whether legal or equitable, or on an agreement for the sale of land, the right of the mortgagee or vendor is restricted to the land to which the mortgage or agreement relates and to foreclosure of the mortgage or cancellation of the agreement for sale, as the case may be, and no action lies

(a) on a covenant for payment contained in the mortgage or agreement for sale;

(b) on any covenant, whether express or implied, by or on the part of a person to whom the land comprised in the mortgage or agreement for sale has been transferred or assigned subject to the mortgage or agreement for the payment of the principal money or purchase money payable under the mortgage or agreement or part thereof, as the case may be, or

(c) for damages based on the sale or forfeiture for taxes of land included in the mortgage or agreement for sale, whether or not the sale or forfeiture was due to, or the result of, the

4. J.J. Catering Ltd. v. 213205 Holdings Ltd., unreported, 1 April, 1981, Q.B. 8003-19277. cf. North West Trust Company v. 247852 Alberta Ltd., unreported, 25 March 1983, Q.B. 8203-30866.

5. R.S.A. 1980, c. L-5.

6. Q.B. 8103.02477.

7. Q.B. 8103-36291. 
default of the mortgagor or purchaser of the land or of the transferee or assignee from the mortgagor or purchaser.

(2) In an action brought on a mortgage of land or on an agreement for sale of land

(a) the order nisi in the case of a mortgage, or the order for specific performance in the case of an agreement for sale, shall direct that if the defendant fails to comply with the terms of the order, the land that is subject to the mortgage or agreement for sale is to be offered for sale at a time and place, in a manner, after any advertisement of sale, and at any price that the court considers proper, and

(b) if the land is not sold at the time and place so appointed, the court may either order the land to be again offered for sale or make a vesting order in the case of an agreement for sale, and on the making of a vesting order or cancellation order, every right of the mortgagee or vendor for the recovery of any money whatsoever under and by virtue of the mortgage or agreement for sale in either case ceases and determines.

(3) Nothing in subsection (2) applies to an order nisi or order for specific performance to which the consent of the debtor has been obtained.

(4) Notwithstanding the provisions of any order nisi or order for specific performance, it is not necessary for the land to be advertised or offered for sale when, subsequent to the making of the order, the debtor consents

(a) to a vesting order in the case of a mortgage, or

(b) to an order of cancellation in the case of an agreement for sale.

(5) Any waiver or release hereafter given of the rights, benefits or protection given by the subsections (1) and (2) is against public policy and void.

\section{Section 42 reads as follows:}

42(1) The time to be fixed for redemption by the order nisi in an action for foreclosure of a mortgage and the time to be fixed for redemption by the order for specific performance in an action on an agreement for sale shall

(a) in the case of farm land be one year from the date of the granting of an order, and

(b) in the case of urban land be 6 months from the date of the granting of the order.

(2) In an action coming under subsection (1), the court on application may decrease or extend the period of redemption having regard to the following circumstances:

(a) when the action is in respect of a security on farm land,

(i) the ability of the debtor to pay,

(ii) the value of the land including the improvements made thereon,

(iii) the nature, extent and value of the security held by the creditor, and

(iv) whether the failure to pay was due to hail, frost, drought, agriculture pests or other conditions beyond the control of the debtor;

(b) when the action is in respect of a security on urban land,

(i) the ability of the debtor to pay,

(ii) the value of the land including the improvements made thereon,

(iii) the nature, extent and value of the security held by the creditor,

(iv) the earning capacity of the debtor, and

(v) whether the debtor's failure to pay was due to temporary or permanent unemployment or other conditions beyond the control of the debtor.

(3) Nothing in this section applies to an order to which the consent of the debtor has been obtained.

It should be noted that $\mathrm{s} .43$ was first legislated in $1964 .{ }^{8}$ Prior to $1939,{ }^{9}$ both a corporation and an individual were liable on their covenants but in that year legislation was enacted to limit the mortgagee to realizing against the land.

\section{PARTIES}

The Rules of Court in Rule 687 provide that a subsequent encumbrancer shall not be made a party in an action for foreclosure except

8. An Act to Amend the Judicature Act, S.A. 1964, c. 40, s. 4.

9. The Judicature Amendment Act, S.A. 1939, c. 85. 
for the purpose of obtaining possession against a subsequent encumbrancer actually in possession of the mortgaged property ${ }^{10} \mathrm{How}$ ever, it has been decided that a caveator protecting a purchaser's interest under an agreement for sale is not a "subsequent encumbrancer" and the caveator must be made a party to a foreclosure action."

It is obvious that the mortgagor needs to be a party to the action and also the present registered owner. If the mortgage has been guaranteed by an individual it is good practice to sue on the guarantee in the foreclosure action and to name the guarantor as a defendant in that action. Using this procedure avoids a multiplicity of actions and keeps the guarantor apprised of what is going on in the foreclosure action. It is, however, possible to sue the guarantor without commencing proceedings against the mortgagor on the land.

A difficult question is whether or not a lessee should be named as a defendant. ${ }^{12} \mathrm{~A}$ lessee is not a subsequent encumbrancer. ${ }^{13}$ If the mortgagee wishes to obtain possession against the lessee, the law is reasonably clear that the lessee should be named as a defendant.

It is common practice, however, not to name the lessee as a defendant. In many foreclosures of commercial or rental property the mortgagee does not want to disturb the tenants as it is the income from the tenancies that make the property attractive to any potential purchaser. There is also the problem that if the lessee is named and then relinquishes the tenancy, then it is necessary to discontinue the action as against the lessee and if a new lessee takes possession it is necessary to add the new lessee as a party. The ususal practice is to not name the lessee as a defendant but to serve the lessee with the order nisi/order for sale and the notice of motion for any final order so as to give the lessee ample notice of the proceedings.

With respect to what parties are necessary as plaintiffs, if there are two or more mortgagees then all need to be parties to the action. They can only advance one claim through one set of solicitors. If one or more mortgagees are not willing to act then that mortgagee or those mortgagees must be made a defendant in the action. ${ }^{14}$

Another point of interest is that if a mortgage has been assigned, then the original mortgagee is not a proper party to the action but the assignee of the mortgagee is the proper party. On occasion a mortgagee will pledge the mortgage as collateral security to its own indebtedness. In those instances proper consideration is often not given as to who should be the proper party. Unless the mortgage is reassigned, the assignee must be the plaintiff. ${ }^{15}$

10. Wasyl Holdings Ltd. v. Allarie (1981) 31 A.R. 275 (Q.B.); Wil-Fran Holdings Ltd. v. Dial Holdings Ltd, unreported, 28 April 1952, Q.B. 8103 - 29253; Canadian Pacific Railway Company v. The Canadian Wheat Growing Company [1919] 2 W.W.R. 313 (Alta. S.C.A.D.); Corwin v. Avery [1925] 1 W.W.R. 811 (Alta. S.C.A.D.).

11. Erikson v. Erikson Holdings Ltd, unreported, 11 August 1981, Q.B. 8103-11467; Travis-Barker v. Reed [1921] 3 W.W.R. 770 (Alta. S.C.A.D.).

12. Wasyl Holdings Ltd. v. Allarie, supra n. 10.

13. Preston Construction Ltd. v. Resteel Consultants Ltd. (1982) 32 A.R. 114 (Q.B.).

14. Hayes v. Bovar [1939] 2 D.L.R. 768 (Ont. S.C.).

15. O'Dwyer v. Banks (1953) 8 W.W.R. 161 (Alta. S.C.A.D.). 
Also, if the mortgagee is a trustee it must show in the statement of claim that the mortgagee is a trustee or the judgment will be a nullity. ${ }^{16}$

\section{TRANSFEREES}

It has now been settled that not only the original corporate mortgagor and the present registered owner are liable on the covenant to pay found in the mortgage, but that any subsequent transferee from the original corporate mortgagor is properly named as a defendant and is liable for the principal and interest owing under the mortgage. This subject was thoroughly canvassed by Master Funduk in the lengthy decision rendered in Humble Investments Ltd. v. Therevan Development Corporation Ltd. ${ }^{17}$

In the Humble case the plaintiffs brought an action against the original mortgagor, all subsequent intervening transferees as well as the registered owner. One of the intervening transferees brought an application to strike out the statement of claim as against itself. It was held that the intervening transferee was a proper party to the action and could be sued on the covenant implied by s.62(1) of the Land Titles Act, notwithstanding the absence of realization against the land.

Section 62(1) of the Land Titles Act reads as follows:

In every instrument transferring land for which a certificate of title has been granted, subject to mortgage or encumbrance, there shall be implied the following covenant by the transferee both with the transferor and the mortgagee: That the transferee will pay the principal money, interest, annuity or rent charge secured by the mortgage or encumbrance, after the rate and at the time specified in the instrument creating it, and will idemnify and keep harmless the transferor from and against the principal sum or other money secured by the instrument and from and against the liability in respect of any of the covenants therein contained or under this Act implied on the part of the transferor.

It is the implied covenant that creates the cause of action. It should be noted, as a matter of practice, that it is necessary to plead the Land Titles Act if there is an intention to rely on the implied covenant in $\mathrm{s.62.}{ }^{18}$

\section{A. WHEN LIABLE}

There is liability when a transferee takes absolutely on the face of the transfer even if the transferee holds as a trustee for himself and others. ${ }^{19}$

If there is one transfer and several transferees, then each is liable for the whole amount outstanding under the mortgage. ${ }^{20}$

Also, if there are several transferees the plaintiff is entitled to sue one or more ${ }^{21} ;$ but that is subject to the rights of those transferees who are sued to apply to have the other transferees joined as parties. ${ }^{22}$ The present common practice seems to be to file third party proceedings against the other subsequent transferees.

16. Walsh v. Smith [1944] O.W.N. 82 (H.Ct. J.).

17. (1982) 21 Alta. L.R. (2d) 40 (M.C.); Colonial Investment and Loan Co. v. Foisie (1911) 1 W.W.R. 397 (Sask. S.C. Chambers); Home Investment and Savings Association v. Middleditch (1914)7 W.W.R. 1202 (Alta. S.C. Chambers); M.G.M. Developments Ltd. v. Black Rose Farms Ltd. (1981) 30 A.R. 274 (Q.B.). See also Que.-Alta. Mortgage Corp. Ltd. v. Humble Investments Ltd, unreported, 11 January 1983, Q.B. 8203-39904.

18. Home Investments and Savings Association v. Middleditch, supra n. 17.

19. Gilbert v. Nester [1923] 3 W.W.R. 15 (Alta. S.C. Chambers).

20. Trusts and Guarantee Company Limited v. Monk (1925) 21 A.L.R. 151 (Alta. S.C.T.D.).

21. Maple Credit Ltd. v. Xomox Investments Ltd., unreported, 2 July 1982, Q.B. 8103 . 26132.

22. Coad v. Windsor [1924] 3 W.W.R. 430 (Sask. C.A.). 
Consideration needs to be given to whether or not a registered owner that becomes registered pursuant to a foreclosure order is subject to the implied covenants of s.62. This question was discussed in another aspect in Douglas v. The Mutual Life Assurance Company ${ }^{23}$ and alluded to in Humble Investments Ltd. $\mathrm{v}$. Therevan Development Corporation Ltdd ${ }^{24} \mathrm{~A}$ good argument could be made that a subsequent mortgagor who takes title by foreclosure or a tenderer in a judicial sale of a subsequent mortgagee is not liable on the personal covenants in the prior mortgage. The Court of Appeal of Alberta in Joyce and Olesky v. Deslauriers and Golden Flow Developments ${ }^{25}$ seems to have come to this conclusion although the facts of that case were so unusual it can be distinguished on that basis.

\section{B. EXCEPTIONS TO LIABILITY}

One exception to liability of a transferee of the original mortgagor is where the transferee is trustee and it is clearly indicated in the transfer that the transferee is taking it as trustee ${ }^{26}$ The exclusion from liability also applies to a transferee who takes as a personal representative of a deceased. ${ }^{27}$ There is no liability when only part of the lands originally covered by the mortgage are transferred..$^{28}$

\section{RESTRICTIONS}

On careful reading of s.62 of the Land Titles Act it should be noted that the implied covenant is restricted to the principal money, interest, annuity or rent charge secured by the mortgage or encumbrance. It should be noted that this restriction to principal monies and interest means that the subsequent transferee is not bound by the covenants to insure or pay taxes. ${ }^{29}$

An interesting question that arises is whether any monies expended to preserve the property pursuant to the mortgage agreement or any legal costs incurred to preserve the security are covered by s.62. Notwithstanding comments by the trial judge in Trusts and Guarantee Company, Limited v. Monk ${ }^{10}$ and the decision of Master Funduk in Que-Alta. Mortgage Corp. Ltd. v. Humble Investments Ltd., ${ }^{31}$ a strong argument can be made that if the mortgage document provides for the charging of expenditures and legal fees and other outgoings and provides that the same will be added to the principal amount owing under the mortgage and become part of that principal, those items are covered by s.62. It might even be that if the clause with respect to insurance and taxes provides that the mortgagee can pay the insurance and the taxes and add them on to the principal sum of the mortgage, then those items can be recovered from a

23. [1918] 3 W.W.R. 529 (S.C.C.).

24. Supra n. 17 at p. 62.

25. Unreported, 15 September 1982, C.A. 15123 (Alta. C.A.).

26. Evans v. Ashcroft and The British Can. Trust Co. (1915) 8 W.W.R. 899 (Alta. S.C.T.D.).

27. Netherlands Investment Company v. Des Brisay [1928] 1 W.W.R. 461 (Alta. S.C.A.D.).

28. The Montreal Trust Company v. Boggs and Beresford (1915) 8 W.W.R. 1200 (Sask. S.C.T.D.); The Dominion of Canada Investment and Debenture Co. Ltd. v. Carstens [1917] 3 W.W.R. 153 (Sask. S.C.A.D.); In Re Macdonald Estate (1925) 21 A.L.R. 66 (S.C.A.D.).

29. Supra n. 20.

30. Supran. 20.

31. Supran. 17. 
subsequent transferee. However, if a subsequent transferee refused to insure the property pursuant to a covenant in the mortgage or refused to pay taxes pursuant to a covenant in the mortgage, foreclosure could not be instituted for breach of those covenants. ${ }^{32}$

\section{CORPORATE COVENANT}

\section{A. REMEDY NOT JUST AGAINST THE LAND}

It was clearly decided in Century 21 Real Estate Ltd. v. Reykdal Investments $L t d{ }^{33}$ by Laycraft J. that a mortgagee has two separate causes of action against a mortgagor. One cause of action is an action for the debt. The other is the right to proceed against the land itself for sale or foreclosure. Section 41(1) of the Law of Property Act procedurally bars an action on a covenant for payment for the actual debt itself, leaving only the right to proceed against the land. However, by virtue of s.43(1) of the Law of Property Act this procedural bar does not apply to a mortgage given by a corporation. It is, therefore, possible to obtain a monetary judgment against a corporate mortgagor and any transferees of a corporate mortgagor. ${ }^{34} \mathrm{~A}$ covenant to pay exists notwithstanding the fact that the land may have been foreclosed by a prior mortgagee. ${ }^{35}$

\section{B. PROCEEDING AGAINST THE LAND FIRST}

In his lengthy decision in Humble Investments Ltd. v. Therevan Development Corporation Ltd. et al rendered on the 19th of April, 1982, ${ }^{36}$ Master Funduk reviews the case law in detail and clearly decides there is no obligation on a mortgagee to proceed with one cause of action before another. The opposite conclusion was reached in Bank of British Columbia v. Pentaco Development Corporation Ltd. ${ }^{37}$ by Master Quinn who found that a mortgagee could not obtain judgment on the covenant to pay before exhausting its remedies against the lands. However, this decision was appealed and reversed by $\mathrm{Mr}$. Justice Legg. ${ }^{38}$ It is therefore possible to obtain judgment on the corporate covenant before first proceeding against the lands. The right to do so is particularly important where it is obvious that there will be a deficiency in the value in the land to cover the amount owing under the mortgage.

\section{WHEN CAN JUDGMENT BE OBTAINED}

It is the usual and preferable practice for a mortgagee to proceed with all causes of action in one statement of claim to avoid duplication of proceedings. A separate action on the covenant is vexatious if there is pending an action for foreclosure in which judgment might have been

32. Central Mortgage and Housing Corporation v. Conaty (1967) 59 W.W.R. 11 (Alta. S.C.A.D.).

33. (1979) 100 D.L.R. 750 (Alta. S.C.T.D.).

34. Wynn v. Rictor Tse, unreported, 16 July 1981, Q.B. 8103 - 10633; First Investors Corporation Ltd. v. Golden Flow Developments Ltd., unreported, 30 December 1981, Q.B. 8003 - 30627; 219193 Holdings Ltd. v. Merdan Industries Ltd., unreported, 12 August 1982, Q.B. $8203 \cdot 18964$.

35. Fernwood Construction of Canada Ltd. v. Century 21 Birch Realty Ltd, unreported, 22 March 1982, Q.B. 8103 - 13058; Ulrich v. Morris (1967) 58 W.W.R. 445 (Man.C.A.).

36. Supra n. 17.

37. [1982] 2 W.W.R. 266 (Alta. Q.B.).

38. 14 May, 1982. 
obtained. At one time there were separate remedies, one in equity and one at law. It was necessary to bring two actions. Now that one action can be brought, they should be in the same pleading. ${ }^{39}$ Judgment on the covenant can be obtained by a separate application or a more common procedure is to apply for judgment at the order nisi stage. However, often counsel will not proceed to judgment at that stage, but will wait until after the land has been advertised for sale and it is determined whether or not there is a deficiency.

It is not uncommon when there is an application for judgment at the order nisi stage to have the court entertain an application for a stay of proceedings either with respect to the application for the judgment or to stay the judgment once it has been granted. However, in any application for a stay of proceedings granted pursuant to s.18 of The Judicature Act, ${ }^{40}$ the granting of a stay is a matter of discretion by the court.

In 1920 ss. 15 was added to s.37 of The Judicature Act ${ }^{41}$ which provided that it was necessary to realize against the land by way of sale of the land first, unless the court ordered otherwise. In 1939 The Judicature Act ${ }^{42}$ was further amended to preclude actions on the personal covenant and to limit realization to the land. This amendment meant that the earlier provision requiring sale before judgment could be realized was no longer applicable. The procedural block to suing on the covenant applied both to an individual and to a corporation. However, in $1964^{43}$ under what is now s.43(1) of the Law of Property Act, corporate mortgagors lost their protection from actions on the covenant. The section requiring the mortgagee to proceed against the land first which was enacted in 1920 was eliminated when the Statutes of Alberta were revised in 1942 and has not been reintroduced.

It is therefore clear that a stay on a judgment on the personal corporate covenant cannot be granted unless adequate reasons are advanced to the court by the mortgagor.

\section{DEFICIENCY JUDGMENT}

Often a mortgagee will not pursue the mortgagor on the covenant until after the land has been advertised for sale. In those instances a deficiency judgment is obtained for the amount outstanding on the mortgage after subtracting any money received from a tender. The date of determining the deficiency is usually the date that the application to accept the tender is made. ${ }^{44}$ Where there has not been a tender, the normal procedure is for the plaintiff to make a proposal to the court to purchase the property for the forced sale on terms value. This figure is usually obtained from the appraisal filed by the plaintiff in the action. It must be made clear that a sale to the plaintiff is not a final order for foreclosure and, therefore, the debt is not extinguished. ${ }^{45}$ The procedure to be followed is set out in the

39. Poulett v. Hill [1893] 1 Ch. 277 (C.A.); Williams v. Hunt [1905] 1 K.B. 512 (C.A.).

40. R.S.A. 1980 , c. J-1.

41. S.A. 1920 , c. 3.

42. S.A. 1939, c. 85 .

43. S.A. 1964, c. 40, s. 4.

44. Commerce Capital Trust v. Kar Industries Ltd., unreported, 1 October 1981, Q.B. 8003 . 17058.

45. Spenrath Construction Ltd. v. 206763 Holdings Ltd. (1981) 15 Alta. L.R. (2d) 136 (Q.B.); affg (1980) 14 Alta. L.R. (2d) 295 (Alta. Q.B. Chambers). 
Court of Appeal decision in Trusts and Guarantee Company, Limited v. Rice. ${ }^{46}$ Basically, that case states that it is inappropriate for a plaintiff to tender on the property and the proper procedure is for the plaintiff to make a proposal to purchase the property after it has been advertised for sale and no proper tenders have been received. Usually a stay is granted on the order and the mortgagor has an opportunity to try to obtain a better price for the land prior to expiry of the stay. The deficiency judgment against the mortgagor is usually obtained upon a further application after the stay has expired and is set at the date of that application. If there is no representation by the mortgagor a stay is not usually granted and the deficiency can be determined as of the date of the application. ${ }^{47}$

\section{REDEMPTION}

It should be noted that a mortgagor, a subsequent encumbrancer and a lessee are entitled to redeem a mortgage..$^{48} \mathrm{~A}$ mortgagor can pay the arrears under s.39 of the Law of Property Act but a subsequent encumbrancer and a lessee must pay the accelerated balance to redeem. ${ }^{49}$ A subsequent mortgagee who becomes the registered owner by reason of foreclosure is entitled to the benefit of s.39. . $^{50}$ Interesting questions arise where there are two co-mortgagors and one is able to make a payment and the other is not. Normally, a co-mortgagor could make a payment for the other co-mortgagor and then have a right of action against the co-mortgagor. There is authority that a part owner of the equity of redemption cannot foreclose another part owner or co-mortgagor even if that first one redeems the mortgage. ${ }^{51}$

Some agreements provide for one co-mortgagor to pay the other comortgagor's share and then rather than have the co-mortgagor who has made payment bring action against the other co-mortgagor, provides by contract for the mortgagor who has made the payment to have a remedy against the defaulting co-mortgagor. The remedy usually allows the defaulting co-mortgagor to reinstate itself, and if it does not, its interest in the property is to be automatically transferred to the other co-mortgagor. The Alberta Court of Appeal in Triple Five Corporation Ltd. v. Eaton Company Limited ${ }^{52}$ found that such a contract was enforceable and the provision did not constitute a clog on the equity of redemption.

46. [1924] 2 W.W.R. 691 (Alta. S.C.A.D.).

47. First Investors Corporation Ltd. v. 98898 Developments Ltd., unreported, 23 February 1982, Q.B. 8103 - 02477; Heritage Savings and Trust Company v. Unicorp International Investments Ltd., unreported, February 1981, Q.B. 8003 - 04035; Nordic Mortgage Corp. v. Beshands Development (Alberta) Ltd., unreported, 3 November 1980, Q.B. 8003 -05741; Signature Finance Ltd. v. C.S. Hook \& Sons Ltd., unreported, 17 June 1981, Q.B. 8003 - 15981; Spenrath Construction Ltd. v. 206763 Holdings Ltd., supra n. 45; First Investors Corporation Ltd. v. Cosmic Holdings Ltd., unreported, 26 February 1982, Q.B. 8103-15415.

48. Maple Credit Ltd. v. Vista West Developments Ltd., unreported, 31 May 1982, Q.B. 8203-05725; Wasyl Holdings Ltd. v. Allarie, supra n. 10; Tarn v. Turner(1888) 39 Ch. D. 456 (C.A.); Capital Trust Corporation Ltd. v. McGuigan [1934] O.W.N. 656 (H.Ct. J.).

49. Country Holdings Development Ltd. v. Roth, unreported, 19 September 1980, Q.B. 7903 .05504; affd by Cawsey J., 24 February 1981.

50. Federal Business Development Bank v. Mid-W Holdings (Edmonton) Ltd., unreported, 17 September 1982, Q.B. $8203 \cdot 13953$.

51. Queen's Park Civil Service Credit Union Ltd. v. Tobin [1972] 3 O.R. 926 (S.C. Chambers).

52. (1977) 4 A.R. 222 (S.C.A.D.). 


\section{REDEMPTION PERIOD}

Section 42 of the Law of Property Act, which sets out the redemption period in a foreclosure action does not apply when the original mortgagor is a corporation by virtue of s.43(1)(b). As a result there is no set redemption period where the mortgagor is a corporation. The standard practice in chambers in Edmonton is to set a redemption period of three months where the mortgagor is a corporation notwithstanding that the mortgagee is well secured.

Consideration must be given to the use of proper terminology. Where the mortgagor is an individual the court will either grant the statutory redemption period or will shorten the redemption period. Where a corporate mortgagor is involved the court sets a redemption period. There is no obligation on the court to be bound by the factors set out in s.42 in determining the redemption period. However, the court does look at the ability of the debtor to pay, the value of the land and the value of the security in determining the redemption period. The court also looks at whether there is any additional security such as guarantees, the amount of arrears, the use to which the lands are being put, the maturity date of the mortgage and when the actions were commenced. ${ }^{53}$

The most common ground for setting a short redemption period is where the amount outstanding under the mortgage is more than the appraised value of the land or where there is very little equity which will be depleted by accruing interest while the redemption period is running. In setting redemption periods the court does not look at the market value of the land but looks at the price that might be obtained on a forced judicial sale.

The court will also look at whether or not the property is rental property and rents are being collected by the mortgagor. In such a case an argument can be made that the mortgagor has an ability to pay and if payment is not being made, then a relatively short redemption period should be set. This approach by the court should lessen the instances where it is necessary to apply for a receiver of rents. It also answers the concern of many mortgagees where a mortgagor is collecting the rent and pocketing it rather than making payments on the encumbrances. The court also looks at whether or not a mortgage has matured. If the mortgage is fully matured and there is an interest rate less than the current market rates then the value of the security is effected and a shorter redemption period can be obtained. ${ }^{54}$

Another factor to take into account in setting a redemption period is whether or not there are subsequent encumbrancers. ${ }^{55}$ Subsequent encumbrancers also have a right to redeem the mortgage under foreclosure but are not served with notice of the application for an order nisi setting the redemption period. The presence of subsequent encumbrancers is relevant in another way. The statutory redemption period for an indi-

53. Bank Of British Columbia v. Willowbrook Homes (1964) Ltd., unreported, 16 June 1980, Q.B. 8003 - 05160; Commerce Capital Trust Co. Ltd. v. Unican Development Corporation Ltd., unreported, 7 July 1980, Q.B. 8003-09543; Bancorp Financial Limited v. Tekarra Properties Ltd., unreported, 29 January 1981, Q.B. 8003-25015; Credit Foncier v. Halmosi, unreported, 18 February 1982, Q.B. $8103-29883$, per Veit J.

54. Credit Foncier v. Halmosi, supra n. 53.

55. Wright v. Gilfoy [1922] 2 W.W.R. 955 (Alta. S.C. Chambers); Maple Credit Ltd. v. Vista West Developments Ltd., supra n. 48. 
vidual is from the date of granting. With respect to corporations where there is no statutory redemption period, where there are no subsequent encumbrances and, particularly, where the mortgagor has by a representative or by counsel made an appearance at the application for an order nisi, the redemption period is usually from the date of granting. However, where there are subsequent encumbrancers and there is a short redemption period the redemption period is usually given from the date of the service of the order nisi/order for sale on the defendant and subsequent encumbrancers. ${ }^{56}$

As a matter of practice it should be noted that Rule 686 (2) which provides that notice to the mortgagor should be given where there is intention to shorten the statutory redemption period is not applicable where there is a corporate mortgagor ${ }^{57}$ As there is no statutory redemption period there is no requirement to give notice. It is normal practice, however, to give notice where the plaintiff seeks a short redemption period but where the plaintiff only wants a three month redemption period with respect to a corporate mortgagor the practice of Master Funduk is not to require notice.

As the value of the property is the prime factor in setting the redemption period some comment needs to be made about the function of an affidavit of value. It is very important to choose a well qualified competent appraiser particularly with the present economic conditions because if the appraisal is not accurate the mortgagee could lose a substantial amount of money. In prior economic times where there were quickly escalating property values if an appraiser was not completely accurate there was very little chance of the mortgagee suffering a loss. However, when values are decreasing and more often than not there is a question as to whether or not there is equity in the property it is important to obtain a detailed appraisal. A decision will have to be made whether or not to apply for a standard redemption period or to apply directly for final order of foreclosure or to apply for a short redemption period plus sale of the property with a view to eventually applying for deficiency judgment. In the past it has been suggested that a detailed appraisal should not be obtained. ${ }^{58}$ However, any appraiser who only gives a superficial appraisal is placing himself at risk in that if a mortgagee suffers a loss because of an inaccurate or superficial appraisal there is liability on the appraiser for the loss. ${ }^{59}$

\section{ALTERNATE REMEDY TO APPLICATION FOR ORDER NISI}

One of the effects of s.41 of the Law of Property Act not applying to a corporate mortgage is that there is no statutory requirement to follow the procedure that is set out in ss.(2) of that section. The subsection requires judicial sale if the mortgage is not redeemed pursuant to the order nisi. As a result where there is very little equity or where the amount outstanding on the mortgage exceeds the value of the land and for some reason it is

56. Maple Credit Ltd. v. Vista West Developments Ltd., supra n. 48.

57. Heritage Savings and Trust Company v. Market Developments Ltd., unreported, 17 August 1981, Q.B. $8003 \cdot 26325$.

58. National Trust Company v. North America Montessori Academy Ltd. [1976] W.W.D. per Master Hyndman, reversed on appeal by Steer $J$.

59. Raylon Investments Ltd. v. Bear Realty Ltd. (1981) 20 R.P.R. 288 (B.C.S.C.). 
decided not to pursue judgment on the corporate covenant or on the guarantees, it is possible to apply directly for foreclosure. The proper procedure is to apply for an immediate final order for foreclosure by way of notice of motion after noting the defendant in default. It is also possible where there has been a statement of defence without merit to apply for summary judgment and a final order for foreclosure in the same notice of motion. Where such remedy is requested it is necessary not only to serve the defendant but also any subsequent encumbrancers and any writ holders. The basis for such an application is set out in the decision in Partners Four Holdings Ltd. v. 124876 Construction Ltd. , a decision of Master Funduk released on the 26th day of November, $1980 .{ }^{60}$

In instances where the mortgagee wishes to have the land advertised for sale, for instance, where the mortgagee wants to pursue a deficiency judgment and is, therefore, required to advertise the land for sale, there is no reason why the mortgagee should not be able to apply directly for an order for sale without the necessity of applying for an order nisi with a redemption period. This procedure, however, does prevent both the mortgagor and the subsequent encumbrancers from redeeming the mortgage. However, there is no reason why the mortgagor and the subsequent encumbrancers cannot still exercise their rights of redemption while the property is being advertised. This procedure is not followed by the Masters in Chambers in the Judicial District of Edmonton but is a procedure sometimes allowed by the Masters in the Judicial District of Calgary.

\section{PARTICIPATION CLAUSE}

Many commercial mortgages contain a participation clause which allows the mortgagee to participate in the income from the property. Mortgagors have been known to deliberately default on a mortgage in order to invoke foreclosure proceedings to allow them to refinance the property elsewhere upon terms that do not include a participation clause. The law with respect to participation clause was canvassed fully in the decision of Cawsey, J. in North American Life Assurance Co. v. Beckhuson. ${ }^{61}$ Where a mortgage containing a participation clause is in default, if the mortgagee commences foreclosure proceedings against the property then the mortgagor's right to redeem may be triggered so that the mortgagor can tender the funds to pay out the mortgage. ${ }^{62}$

However, if the mortgagee wishes to protect its participation clause and either the mortgage is in default or the participation payment has not been made, then the mortgagee should not commence foreclosure proceedings but should bring an action asking for an accounting with respect to the participation clause and payment for the amount due thereunder. This type of action, if properly pleaded, does not trigger the right to redeem. If a mortgage with a participation clause is in default with respect to principal and interest, then a simple action in debt should be brought for the arrears only and an application should be made in that action for a receiver of rents to ensure that further payments under the mortgage are made. If foreclosure proceedings are brought, however, the right to redeem is triggered and the participation clause can be lost.

60. Unreported, Q.B. 8003-22631.

61. (1980) 18 R.P.R. 22 (Alta. Q.B.).

62. Heritage Savings and Trust Company v. Harke [1980] 3 W.W.R. 308 (Alta. S.C.A.D.); Beck v. Investors Group Trust Co. Ltd. (1978) 4 Alta. L.R. (2d) 1 (S.C.T.D.). 


\section{LEASES}

It is settled law that a lessee has a right to redeem a mortgage in a foreclosure action. ${ }^{63}$ The right of redemption is to pay out the accelerated balance owing under the mortgage, not the right to pay arrears given the mortgagor in s.39 of the Law of Property Act. Reference should be made to the prior discussion as to whether or not a lessee should be made a party to foreclosure action. Normally, a lease is registered subsequent to mortgage financing and, if registered prior, a postponement is given to the mortgagee. As a result, the mortgage in most instances is prior to the lease and if the mortgagor falls into default, there is a possibility that the lessee's interest could be foreclosed from the title. ${ }^{64}$ The Landlord and Tenant Act ${ }^{65}$ does not apply in foreclosure proceedings. ${ }^{66}$ Unless the property is advertised subject to the lease, the successful tender is usually entitled to receive the property vacant thirty days after the lessee has been served with the order confirming sale. Likewise, where a final order for foreclosure is taken, the lessee is usually given thirty days notice to vacate the premises. There is some suggestion in Falconbridge on Mortgages ${ }^{67}$ that if a lease is subsequent to a mortgage, but with the mortgagee's authority, the lessee's interest is paramount to the mortgage. It is not thought that this is accepted law in the Province of Alberta.

The fact that the lessee has the right to redeem a mortgage under foreclosure means that great care should be taken to protect a lessee when drawing up lease documents. The lease should include a clause that the lessee has a right to redeem the mortgage and offset any rental payments due against any funds paid to the mortgagee in redemption of the mortgage. When a lease is initially being negotiated if possible a non-disturbance agreement from any prior mortgagees should be obtained. As most mortgage companies are concerned that rental property can, in fact, be rented and yield income and would prefer to take a final order of foreclosure on a building fully rented and as, in most instances tenderers, if they are purchasing a property for its income, wish to have the property rented, it is easier to obtain a non-disturbance agreement when a lease is being negotiated than when the property is under foreclosure.

It is also important when acting for lending institutions and taking a mortgage of a leasehold interest to provide in that mortgage that the mortgagee can, through the lessee/mortgagor and by using the lessee's payments under the mortgage of the leasehold interest, redeem the mortgage on the fee simple estate.

\section{INSURANCE}

Some brief comments need to be made about insuring mortgaged premises. As noted earlier, where there is a subsequent transferee of an original mortgagor, s.62 of the Land Titles Act does not imply a covenant to insure. ${ }^{68}$ Therefore, a mortgagee must take particular care to ascertain

63. Wasyl Holdings Ltd. v. Allarie, supra n. 10.

64. Supra n. 13.

65. R.S.A. 1980 , c. L-6.

66. Co-operative Trust Company of Canada v. Laycock (1980) 13 Alta. L.R. (2d) 6 (Q.B.).

67. W.B. Rayner and R.H. McLaren, Falconbridge on Mortgages (4th ed., 1977) 326.

68. Supra n. 20. 
that the mortgaged premises are covered by fire insurance and further that the mortgagee is an appropriate loss payee. The mortgagee should also make sure that it has an arrangement with the insurance agent that it be notified the minute there is non-payment of the insurance premiums. Otherwise, the mortgagee should arrange to insure the property itself, notwithstanding the fact that unless the mortgage is very carefully drawn, it may be that those premiums cannot then be charged back against the mortgagor. In Re Powell ${ }^{69}$ it was found that the mortgagee in that instance should receive the proceeds of insurance in priority to other creditors. The covenant in the mortgage document to insure the buildings coupled with the placing of insurance, albeit with non-disclosure of the mortgage or the covenant to insure, created an equitable interest by the mortgagee and a lien on the insurance monies to the extent of the mortgage debt. The express reason why priority was granted was that there was a covenant contained in the mortgage document. However, the prior claim of the mortgagee would not have been effective if the insurance company had not received notice before payment of the insurance proceeds to the insured. If there had been no express or implied covenant in the mortgage, it is likely that the decision would not have given the mortgagee priority over the other creditors.

Where there is no duty to insure the premises and the defendant does insure the building to its full value the defendant is taken to have insured the interest of the mortgagee as well as of its own. ${ }^{70}$ In these instances, the mortgagee is entitled to that portion of the insurance money as the amount owing on the mortgage is to the total value of the building and land. Therefore, if there is no covenant to insure and the mortgagor does insure to full value then it can be implied that the mortgagee's interest is insured. However, in order to gain priority over execution creditors it would also be necessary for the mortgagee to have itself named as a priority loss payee.

\section{INTEREST}

The Interest Act ${ }^{71}$ provides for interest on judgments at a statutory rate of 5 percent. However, if there has been, by contract, a different rate specified other than the statutory rate to apply after judgment then the rate that has been contracted for applies. ${ }^{72}$ The language in the contract must be explicit in order for interest to run at the rate in the mortgage after judgment. ${ }^{73}$ The sufficiency of various clauses was fully canvassed by Master Funduk in Maple Credit Ltd. v. Xomox Investments Ltd. and Remic Development $L t d .{ }^{74}$ In order to claim interest at the mortgage rate on a judgment against the corporate mortgagor on its covenant or against a guarantor, interest at the contract rate after judgment must be specifically pleaded in the statement of claim and must be asked for in clear terms in the notice of motion applying for the same.

69. (1979) 6 R.P.R. 310 (N.S.S.C.T.D.).

70. Battersby v. Lenhoco Enterprises Ltd. (1980) 14 R.P.R. 252 (Sask. C.A.).

71. R.S.C. 1970 , c. I-18, s. 13.

72. Supra n. 45.

73. Bank of Nova Scotia v. U.P.C. Holdings Ltd. (1980) 11 Alta. L.R. (2d) 331 (Q.B.); Tessier v. Van Ed Block Developments Ltd., unreported, 1 March 1982, Q.B. 8103.34946.

74. Supran. 21. 
Where the contract does not provide for interest at the mortgage rate after judgment some potential problems arise. An order nisi is a judgment. However, it has been found that interest in a foreclosure action continues to run at the mortgage rate after the order nisi. If the mortgagor wishes to redeem after the order nisi, interest must be paid until the date of redemption at the mortgage rate. However, if judgment is taken on the corporate covenant or against the guarantor at the order nisi stage, then interest against those parties would drop to the $5 \%$ rate set out in the Interest Act. Where the property is not redeemed and is sold by way of a tender in a judicial sale and the tender monies are ready to be paid out of court, an issue could arise as to whether or not the mortgagee is entitled to interest from the date of the order nisi at the mortgage rate or at the statutory rate. ${ }^{75}$

\section{CHATTEL SECURITY}

Many loans of a commercial nature are secured not only by a land mortgage but also by a chattel mortgage. This is particularly true where there is residential rental property and each rental unit is equipped with a refrigerator and a stove. It is prudent to realize on the chattel security at the same time as the land security. Realization on chattel security is particularly important for situations where after land has been offered for sale and there have been no tenders, an application for a final order for foreclosure is contemplated. If a final order for foreclosure is obtained then the debt is extinguished and those items covered by the chattel security are, in effect, released.

It is of particular importance to realize on the chattels at the same time as the land where property is residental rental property and chattels are necessary for the ongoing use of the land. With most residential rental property the appraisal done by the appraiser is on an income basis which involves the ongoing rental of the property which would be disturbed if, for instance, the stoves and refrigerators were removed. There are instances where mortgagees have foreclosed on their land security and after the final order for foreclosure has been obtained, the mortgagor has demanded return of the stoves and refrigerators and has been entitled to them.

There are two methods for realizing on chattel security. The first is to foreclose by way of statement of claim, not only on the land, but also on the chattels. This procedure was set out in the decision in Krook v. Yewchuk. ${ }^{76}$ It is very efficient for the foreclosure on both the land and chattel security to proceed in tandem. An order nisi/order for sale is obtained with respect to the chattels and they are advertised for sale with the land security. The appraisal that is obtained pursuant to the land mortgage will also include the chattels. It is possible for the mortgagee to foreclose on both the land and chattels or to accept a tender on both. ${ }^{77}$ The difficulty that arises in proceeding this way is that chattels have a habit of disappearing and it is sometimes not easy to ascertain if the chattels covered by the security are still in possession of the mortgagor. Difficulties could arise if all the

75. Supran. 21.

76. [1962] S.C.R. 535.

77. Northland Bank v. 208633 Holdings Ltd., unreported, 5 May 1982, Q.B. 8103-21186. 
chattels listed on the chattel mortgage are offered for sale and tenders are received on them and when the successful tenderer takes possession the chattels have disappeared. When pursuing foreclosure of chattels by way of statement of claim it is often necessary to exercise the powers of inspection under the chattel mortgage and to enter the premises to take an inventory of the chattels.

The other way to realize concurrently on chattel security is to cause a seizure to be effected under the Seizures Act. ${ }^{78}$ Whether or not a notice of objection is received, an application is brought concurrently with an application for an order nisi/order for sale of the land to sell the chattels that have been seized with the land. The chattels are then concurrently advertised for sale in the same judicial notice and it is then possible to sell the chattels. There is still some hesitation as to whether or not the mortgagee can take the seized chattels with the land by way of a final order for foreclosure. However, in Lennie v. L.D.M. Holdings Ltd. ${ }^{79}$ the plaintiff applied to the court to accept a proposal by the plaintiff to purchase the land and chattels which was accepted by the court. The advantage of the seizure procedure is that the Sheriff attends upon the premises where the chattels are located and provides an inventory of what chattels are still in the existence, and this inventory can be used for the purposes of sale. This method, however, is somewhat more cumbersome than merely foreclosing on the chattels.

Whatever method is used, it is clear that some method of realizing on the chattels must be undertaken. It is not possible to ask the court to sell the chattels as part of some later application with respect to the land where nothing has been done to realize on the chattel security by one of the two accepted methods. ${ }^{80}$

Frequently, a lender will take a debenture that covers both lands and chattels. In such instances, it is possible to appoint a receiver extrajudicially to sell both the lands and the chattels. However, such an appointment of a receiver cannot be done only in respect to the property specifically covered by the security where there is also a floating charge unless the security so provides. A lender may also find that the receiver is obligated to sort out all the financial affairs of the company when the mortgagee only wishes to realize on its security.

In those instances, it is possible to foreclose against the land and chattels or to foreclose against the land and to seize the chattels and have both sold pursuant to court direction. Sometimes lenders obtain a land mortgage, a chattel mortgage and a debenture to secure a loan. Taking this type of security gives more flexibility in deciding how to realize should there be default. The decision in Federal Business Development Bank v. Red Lion Restaurant Ltd $^{{ }^{81}}$ is interesting in that Mr. Justice Moore found that notwithstanding the fact the lender had obtained an order nisi he could later appoint a receiver under the debenture. The court rejected the submission of the borrower that the lender had elected when it proceeded to foreclose on the mortgage. The debenture would only be affected when foreclosure took place.

78. R.S.A. 1980 , c. s-11.

79. Unreported, 27 September 1982, Q.B. 8203-05044.

80. Supra n. 77.

81. (1979) 10 Alta. L.R. (2d) 187 (S.C.T.D.). 


\section{GUARANTEES OF CORPORATE MORTGAGES}

A vast majority of corporate mortgages are guaranteed by individuals, usually the principals of the corporations. Most of the issues that arise in realizing against guarantors of corporate mortgages are procedural.

First of all, when the original mortgagee assigns its interest and there are guarantees of the mortgage, it is essential that those guarantees also be assigned as well as the mortgage, particularly where they are not contained in the mortgage filed at the Land Titles Office. ${ }^{82}$

The common practice is to sue the guarantor in the same statement of claim in which the foreclosure proceedings against the land are brought. There has recently been debate on whether or not immediate judgment can be obtained against the guarantor. ${ }^{83}$ In the Court of Appeal of Alberta in Credit Foncier v. Edmonton Airport Hotel Co. Ltd. and Superstein ${ }^{84} \mathrm{Mr}$. Justice Kane devoted a paragraph to suggesting that there should be realization against the land first before judgment is realized against the guarantor. That aspect of his judgment was not commented upon by the Supreme Court of Canada when the case was before it. This subject was recently dealt with in detail by Master Funduk in RoyNat Inc. v. 217678 Holdings Ltd. $^{85}$

Master Funduk reviews the Superstein case in detail and reaches the conclusion that what was granted was a de facto stay of proceedings and that recent decisions of the Court of Queen's Bench indicate that a mortgagee can proceed to realize on his security in the order he chooses with the only limitation being s.44(1) of the Law of Property Act.

On the basis one can obtain immediate judgment against a guarantor, a further question arises as to whether or not the court will exercise its discretion and allow a stay of proceedings against the guarantor on the judgment until such time as there has been a sale of the lands. However, the court will only consider exercising its discretion upon the application of the guarantor and for just cause. ${ }^{86}$

In obtaining judgment against a guarantor of a corporate mortgage, notwithstanding the guarantor may have been noted in default, the court requires proof of the guarantee and the amount outstanding under it. The allegations in the statement of claim by themselves are not sufficient. ${ }^{87}$

In applying for judgment against a guarantor who has been noted in default, it should be noted that the rules do not require service of a notice of motion for judgment. ${ }^{88}$

A mortgagee often chooses to attempt to sell the land first and then if there is a tender that is less than the amount outstanding, obtain deficiency judgment or, if the land is worth less than the amount outstanding

82. Supra n. 35.

83. Supra n. 37;reversed on appeal by Legg J., 14 May 1982; Consept Mortgage Corporation Ltd. v. Berg, unreported, 28 January 1982 , Q.B. $8103-28205$; reversed on appeal by Legg J., 13 May 1982.

84. (1964) 48 W.W.R. 641 at 684 (Alta. S.C.A.D.).

85. (1982) 23 Alta. L.R. 33 (M.C.).

86. Karo Realty \& Developments Ltd. v. 209782 Holdings Ltd., unreported, 18 July 1980 , Q.B., 7903-01832; supra n. 17.

87. Tessier v. Van Ed Block Developments Ltd., supra $\mathrm{n} .73$.

88. Rule 144. 
and there are no tenders, to make a proposal to the court to purchase the property and obtain an order in the nature of Trusts and Guarantee Company Limited v. Rice. ${ }^{89}$ If no one opposes the application by the plaintiff putting forward a proposal to purchase the property, and the proposal is accepted, it is the practice of the court not to order a stay on the sale to the plaintiff in order to allow the guarantor time to bring in a better offer. Usually the orders in those instances are made effective immediately and the deficiency judgment is set as at the date the order is granted. Where a guarantor for the corporate mortgagor opposes the application for sale to the plaintiff, then of ten a stay is placed on the judgment to allow the defendant to bring in a better offer for the property. In those instances deficiency judgment is not usually granted from the date of the order, but it is necessary to bring a later application to determine the deficiency as of the date of the subsequent application. Other variations of the date to set the deficiency are acceptable and depend on the circumstances of the individual case.

Notwithstanding that the property has been transferred and the mortgagor for whom the guarantee was given is no longer the registered owner, the guarantor is still liable under the guarantee if there is default in the payment of principal and interest under the mortgage. It is unusual for a mortgagee to release the guarantor when the property is transferred. There is an Ontario decision where the original mortgagor transferred the property to two corporations who then transferred the property to the then registered owner. That registered owner had guaranteed the mortgage given to the plaintiffs by the first mortgagor. While the intervening transferees were the registered owner of the property an agreement was reached with the mortgagee to release the intervening transferees from any liability under the mortgage. The registered owner was sued as the guarantor of the original mortgage. The court found that the only way that the defendant as a guarantor would be released was if the original mortgagor had been released. ${ }^{90}$

Certainly there is authority that if a mortgagee grants time to a mortgagor for the payment of instalments, the guarantor is released from that instalment. However, that does not release the guarantor from other payments owing under the mortgage. ${ }^{91}$

Most standard form guarantees now in use allow for accommodation to be made to the original mortgagor or its transferees without affecting the guarantee.

The question arises as to whether or not if the mortgage has matured and if there has been a renewal at a higher interest rate, the guarantor is released. The Supreme Court of Canada in Holland-Canada Mortgage Co. v. Hutchings et $a^{l^{2}}$ found that a renewal or an extension with an increased rate of interest is a definite alteration of a material part of the original contract, and sufficient to release a guarantor. A guarantee can also be affected by release of part of the security unless there are explicit provisions allowing for the same under the guarantee. Perhaps it need not be

89. Supra n. 44.

90. Skoratz v. Ridgeport Developments Ltd. (1980) 14 R.P.R. 128 (Sask. C.A.).

91. Holland-Canada Mortgage Co. v. Hutchings[1963]2 D.L.R. 481 (S.C.C.).

92. Id. 
said that where one takes an order for foreclosure and extinguishes the debt owed under the original mortgage then, of course, there will be no remaining liability on the guarantor.

\section{SUMMARY}

The major factor influencing the foreclosure of corporate mortgages was the 1964 Amendment to The Judicature Act that resulted in the mortgagee not being restricted to recovery against the land. In more recent years that amendment along with the attitude of the court has meant that more attention has been paid to judgment on the corporate covenant, judgment against guarantors and realization on other collateral security.

Of particular significance has been the recent change in the timing of the realization of other security in relation to the land.

The present attitude of the court is to allow foreclosure of corporate mortgagees and realization on guarantees of such mortgages as expeditiously as possible given the circumstances. Much of the procedure and principles of law have been documented in the numerous recent decisions, greatly clarifying and modernizing this area of practice. 